\title{
History, Oral History and Archaeology: Reinterpreting the "Boat Places" of Erebus Bay
}

\author{
Douglas R. Stenton ${ }^{1}$ and Robert W. Park ${ }^{2}$
}

(Received 11 August 2016; accepted in revised form 11 January 2017)

\begin{abstract}
Historical and archaeological records are examined for three archaeological sites at Erebus Bay, King William Island, associated with the 1845 John Franklin expedition. Comparison of 19th century historical descriptions with archaeological data from sites $\mathrm{NgLj}-1$ and $\mathrm{NgLj}-3$ establishes that the identification of $\mathrm{NgLj}-1$ as the site of the $1859 \mathrm{McClintock}$ "boat place" is incorrect and that $\mathrm{NgLj}-3$ is the actual site. An assessment of 19th century oral historical information and contemporary archaeological data from NgLj-2 supports the conclusion that a ship's boat from the Franklin expedition was once located at the site, but its identification as the second "boat place" discovered by Inuit in 1861 is problematic. The study underscores interpretive risks associated with uncritical acceptance of historical and oral historical accounts and the importance of archaeological research in the reconstruction of events surrounding the fate of the Franklin expedition.
\end{abstract}

Key words: Franklin expedition; archaeology; Erebus Bay; oral history; King William Island; cannibalism; boat places

RÉSUMÉ. Des enregistrements historiques et archéologiques de trois sites archéologiques de la baie Erebus, île King William, sont examinés en lien avec l'expédition de John Franklin en 1845. La comparaison des descriptions historiques du XIX ${ }^{e}$ siècle avec les données archéologiques des sites NgLj-1 et NgLj-3 permet d'établir que l'identification de NgLj-1 comme site de l'« emplacement du bateau » de McClintock en 1859 est incorrecte et que NgLj-3 est le vrai site. L'évaluation d'information historique orale du XIX ${ }^{\mathrm{e}}$ siècle et de données archéologiques contemporaines de $\mathrm{NgLj}-2$ vient appuyer la conclusion selon laquelle un bateau du navire de l'expédition a déjà été repéré au site, mais son identification en tant que deuxième « emplacement du bateau » découvert par les Inuits en 1861 est problématique. Cette étude fait ressortir les risques d'interprétation liés à l'acceptation exempte de critiques de données historiques ou de récits oraux historiques de même que l'importance de la recherche archéologique dans la reconstruction des événements entourant le sort de l'expédition Franklin.

Mots clés : expédition Franklin; archéologie; baie Erebus; histoire orale; île King William; cannibalisme; emplacements du bateau

Traduit pour la revue Arctic par Nicole Giguère.

\section{INTRODUCTION}

Erebus Bay, a large bay on the southwest coast of King William Island, Nunavut, is one of several locations that bear witness to the tragic events that followed the desertion of HMS Erebus and HMS Terror in April 1848 (McClintock, 1859; Cyriax, 1939; Klutschak, 1987) (Fig. 1). The importance of Erebus Bay first became evident in May 1859, with the discovery of a ship's boat there by the Franklin search expedition led by Francis Leopold McClintock (McClintock, 1859). The boat was found resting on the sledge on which it had been drawn and contained a large quantity of equipment and supplies, along with the partial skeletal remains of two individuals (Hobson, 1859; McClintock, 1859; Stenton, 2014).

Word of the discovery of a qallunaat (white man's) boat in Erebus Bay spread among local Inuit, and in what was likely the spring of 1861, a small group of Netsilingmiut traveled there to search for items left by the Franklin crew members (Hall, 1869; Nourse, 1879). When interviewed several years later, they reported finding two ship's boats from the Franklin expedition, one of which they concluded to be the same boat previously found by McClintock. The second boat site was situated a relatively short distance from the first and contained very similar items, including an apparently large quantity of human skeletal remains (Hall, 1869:257; Nourse, 1879:419-421).

Nearly two decades later, in 1879, Frederick Schwatka conducted a search on King William Island for records from the Franklin expedition that were rumoured to still exist (Schwatka, 1965). Schwatka's search area included approximately $80 \mathrm{~km}$ of the west coast of King William Island between Cape Felix, at the northern tip of the island, and Erebus Bay. Schwatka visited several of the sites previously discovered by the McClintock expedition, and on the shore of one of the small bays indenting the coastline

\footnotetext{
${ }^{1}$ Corresponding author: Department of Culture and Heritage, Government of Nunavut, PO Box 1000, Station 800, Iqaluit, Nunavut X0A 0H0, Canada; Dstenton1@gov.nu.ca

${ }^{2}$ Department of Anthropology, University of Waterloo, Waterloo, Ontario N2L 3G1, Canada; robert.park@uwaterloo.ca

(C) The Arctic Institute of North America
} 


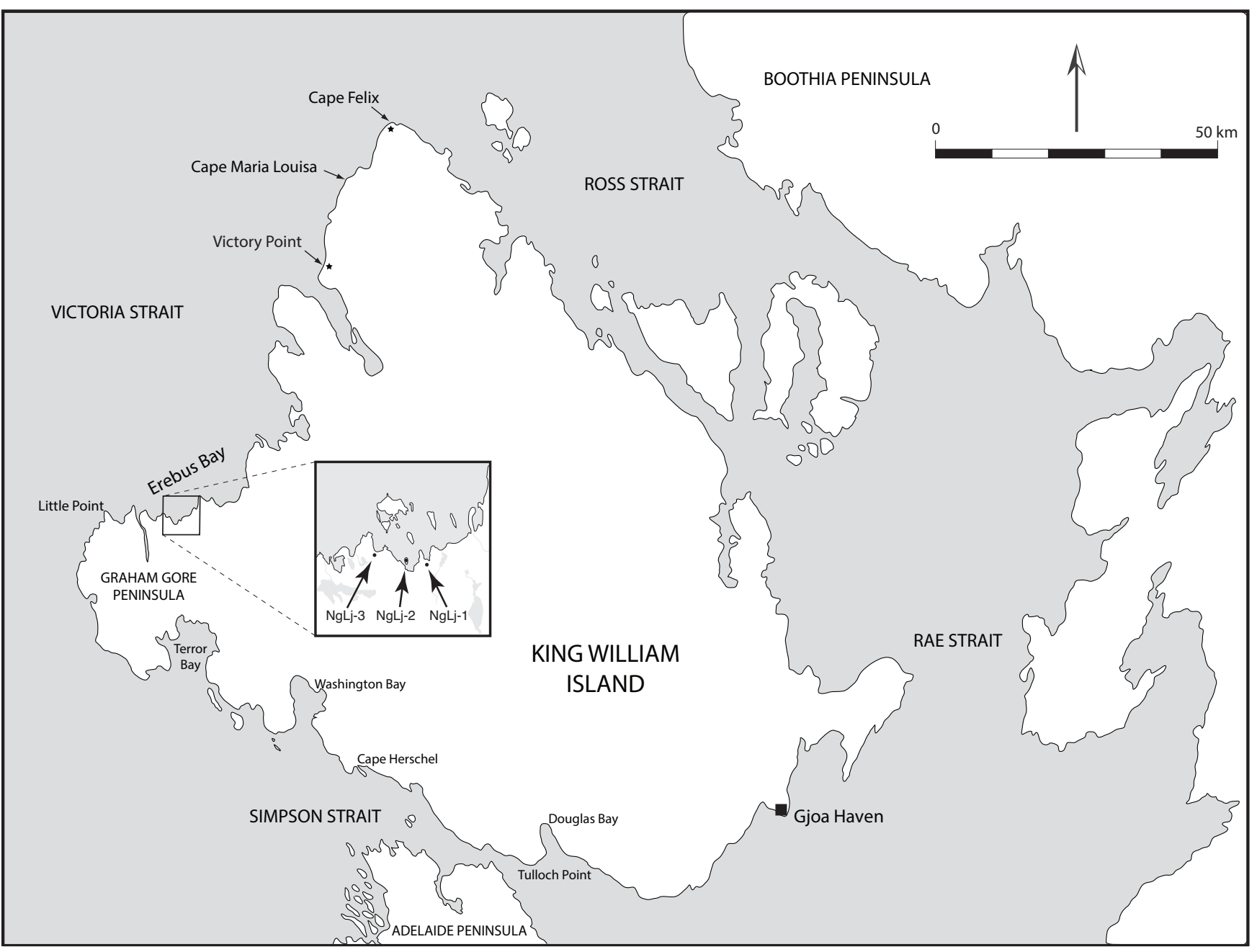

FIG. 1. Map of King William Island showing site locations discussed in the text.

of southern Erebus Bay, he found the partial wreckage of a ship's boat, naval artifacts, and human skeletal remains strewn along and near the high-water mark. The skeletal remains, thought to represent four individuals, were collected and buried (Gilder, 1881; Schwatka, 1965; Klutschak, 1987; Stenton et al., 2015), and a small number of artifacts, including the boat's stem, were removed from the site. The party was familiar with the reports of a second boat discovered nearby by Inuit, but a search for it was unsuccessful.

These 19th century discoveries in Erebus Bay distinguished it as a location of importance to understanding the chronology of the Franklin expedition after April 1848, when HMS Erebus and HMS Terror were deserted. In addition to their intrinsic historical significance, these findings have figured prominently in speculative inferences of certain post-desertion events, such as the re-manning of the ships (McClintock, 1859) and the postulated besetment of HMS Erebus and HMS Terror in Erebus Bay (Woodman, 1991). It should be noted that use of the word "deserted" instead of "abandoned" to describe the event of 22 April 1848 is intentional: it follows the wording used by Captain Fitzjames in his note found in
1859 in a cairn near Victory Point, where the 105 survivors had assembled three days after deserting the ship.

Notwithstanding these important discoveries, the first actual archaeological investigations at Erebus Bay occurred more than a century later in 1982, when Owen Beattie surveyed the western shore of King William Island between Cape Maria Louisa and Little Point. Along the shoreline of a small bay near the southern extremity of Erebus Bay, he discovered several Franklin expedition artifacts and a small quantity of human skeletal remains. One location (Bay 3) (see Fig. 2), thought to be the probable source of the materials, was inferred to be the place where McClintock had found the boat in 1859 (Beattie, 1982, 1983) and was later assigned Borden number $\mathrm{NgLj}-1$ in the Canadian archaeological site designation system.

Ten years after the discovery of $\mathrm{NgLj}-1$, amateur historian Barry Ranford discovered Franklin artifacts and abundant human skeletal remains on the north end of a small, flat tidal islet located approximately $1.2 \mathrm{~km}$ west of NgLj-1 (Ranford, 1992). This site ( $\mathrm{NgLj}-2$ ) was investigated the following year by archaeologist Margaret Bertulli, who interpreted it to be the probable location of the second ship's boat discovered by Inuit in 1861 (Bertulli, 1995:16). 


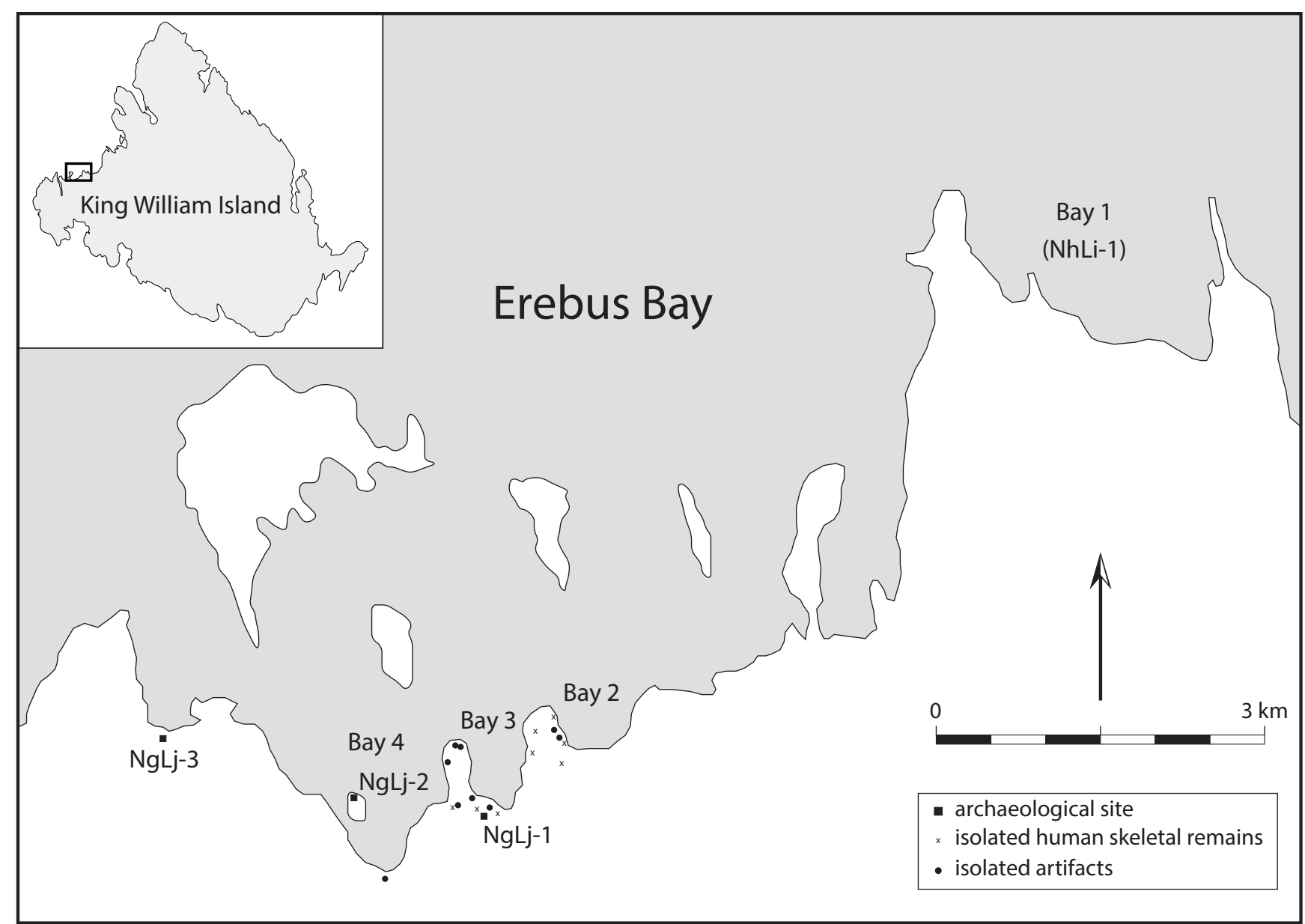

FIG. 2. Map showing approximate distribution of artifacts and human remains recovered from NgLj-1 in 1982. Locational data courtesy of Owen Beattie.

Ranford participated in the 1993 investigations at $\mathrm{NgLj}-2$, and in the course of conducting additional searches nearby, he discovered another site containing Franklin expedition boat fragments, artifacts, and human skeletal remains$\mathrm{NgLj}-3$ - approximately $1.7 \mathrm{~km}$ west of $\mathrm{NgLj}-2$ (Bertulli, 1995:17). The site was partially mapped in 1994 and was tentatively identified as the probable site described by Schwatka in 1879 (MacDonald, 1996:6).

Thus, 19th century European reports and Inuit oral historical accounts had described the discovery of two ship's boats from the Franklin expedition on the shores of southern Erebus Bay, but late 20th century archaeological investigations identified three sites in southern Erebus Bay, located within relatively short distances of each other, and each was interpreted to be a place where a ship's boat from the Franklin expedition had once been located. Whether there were two ships' boats or three, this small locality has yielded the largest known assemblage of archaeological evidence of the Franklin crew's escape attempt. These sites have also produced by far the largest assemblage of human remains from the expedition and provided important insights concerning morbidity and mortality, as well as physical evidence for certain cannibalistic behaviours among some of Franklin's men (Keenleyside et al., 1997).
Current reconstructions of events and activities thought to have occurred at Erebus Bay have relied primarily on the reports of 19th century searches and the testimony of contemporaneous Inuit oral history. Those accounts are crucially important because some contain the original, first-hand descriptions of sites that later underwent radical transformation prior to being investigated by archaeologists. A factor contributing to this reliance on historical information has been the limited nature of the available archaeological data. Over the past 40 years, professional and avocational archaeologists, historians, and adventurers have searched for Franklin expedition sites on western and southern King William Island. However, with few exceptions, these investigations have consisted of site surveys, many of which by their nature yielded data that, while potentially important, has seen limited use in contemporary archaeological analyses. The Erebus Bay human remains have been relatively thoroughly examined in various publications (Beattie, 1983; Keenleyside et al., 1997; Stenton et al., 2015), but the nature and distribution of artifactual material have not been studied in detail, and most of the site data have not been published. This omission is significant because researchers attempting to reconstruct events that occurred at Erebus Bay have interpreted the very limited archaeological data through the 
lens of the 19th century search reports and the testimony of contemporaneous Inuit oral history. When site attributes were not obviously inconsistent with the historical accounts, the latter were accepted uncritically. Now that more detailed archaeological data are available from Erebus Bay, it is possible to re-examine some of these conclusions.

In this paper, we compare the British, American, and Inuit 19th century descriptions of the "boat places" in Erebus Bay with the archaeological data acquired from these sites over the past 35 years to examine two specific questions. We first consider which of the three archaeological sites in southern Erebus Bay is the site found by the 1859 McClintock expedition. We then evaluate whether any of the sites can be identified with confidence as the location of the second ship's boat discovered by Inuit in 1861 .

\section{HISTORICAL ACCOUNTS}

Historical information about the Erebus Bay boat sites is contained in several documents that describe events occurring between May 1859 and July 1879. These sources include the published and unpublished accounts of the British search expedition of 1857-59 led by Francis Leopold McClintock (Hobson, 1859; McClintock, 1859), Charles Francis Hall's records of his 1869 interviews with Inuit concerning the boat sites (Hall, 1869; Nourse, 1879), and the published accounts of Frederick Schwatka's 1878-80 search for records from the Franklin expedition (Gilder, 1881; Schwatka, 1965; Klutschak, 1987).

\section{The 1857-59 McClintock Expedition}

The first discovery of a boat from the Franklin expedition on the west coast of King William Island was made by a search party led by Lieutenant William R. Hobson, McClintock's second-in-command on the twoyear search expedition aboard the yacht Fox (McClintock, 1859). On 24 May 1859, while leading a small party of searchers northward along the west coast of King William Island, Hobson found the boat on the shore of southern Erebus Bay. It was found close to the water's edge, and its dimensions were recorded as 28 feet in length, with a beam of 7 feet, 6 inches and a depth of 2 feet, 6 inches. It was heeling considerably to starboard, unsecured to the sledge and partially lifted from the chocks into which it had been fitted. Hobson described it as "...large and lightly built for transport over ice, sharp alike at bow and stern with mahogany floor and fir upper works" (Stenton, 2014:517). On a previous expedition in 1839, HMS Erebus and HMS Terror had each been fitted with the same number (nine) and types (six) of boats, two of which (one on each ship) were 28 -foot pinnaces. None of the other boats were 28 feet in length; thus, if both ships were similarly outfitted in 1845 , the boat found by Hobson was a pinnace.

Over a two-day period, Hobson and his party completed an extremely thorough search of the boat's contents in the hope of finding documents that might offer clues about the fate of the expedition. No such documents were found, but Hobson did find the skeletal remains of two individuals and a large and diverse collection of supplies and equipment, including guns, ammunition, paddles, clothing, and other personal possessions such as silverware, watches, and books (McClintock, 1859: Appendix III; Stenton, 2014:517-520).

Hobson retained a sample of the "relics" found in the boat and departed the site on the morning of May 26. McClintock, whose party was searching the eastern and southern shores of King William Island, arrived at the site four days later and conducted a second exhaustive search of the boat and its immediate surroundings (McClintock, 1859:290-300). McClintock also retained some of the items found, but neither he nor Hobson appears to have had any special interest in the human remains they found or made any effort to inter them or to remove them for later burial in Britain.

Hobson recorded the boat's location to be $69^{\circ} 09^{\prime} \mathrm{N}$ and $99^{\circ} 28^{\prime} \mathrm{W}$ (Stenton, 2014:518). McClintock recorded two sets of coordinates for the site: one set for the items that he removed $\left(69^{\circ} 08^{\prime} 43^{\prime \prime} \mathrm{N}\right.$ and $\left.99^{\circ} 24^{\prime} 42^{\prime \prime} \mathrm{W}\right)$ and a second set for the items that were not collected $\left(69^{\circ} 09^{\prime} \mathrm{N}\right.$ and 99 24' W) (McClintock, 1859:367). McClintock's purpose in recording two sets of coordinates for the same location is curious, especially given the fact that it is unlikely that the items he and Hobson left behind had been moved any significant distance from the boat and sledge, or that they would otherwise be difficult for later investigators to relocate.

The boat was discovered 11 years after the desertion of HMS Erebus and HMS Terror, and it is clear from Hobson and McClintock's detailed description of its condition that its existence had been unknown to Inuit. Apart from some carnivore scavenging of the human remains, and possible impacts of wind, water, and ice (e.g., movement of the boat, hole in the starboard side), the boat was undisturbed. No structural features of any type (e.g., caches, graves, cairns, tent rings) were observed at the site, but because the boat was discovered in the spring and was almost completely buried beneath snow, some types of built features, if present, might have been concealed. Note, however, that in other locations south of Erebus Bay, especially between Graham Gore Peninsula and the Cape Herschel area, Hobson reported seeing numerous Inuit summer camps consisting of tent rings and caches (Stenton, 2014:517).

\section{The 1869 In-nook-poo-zhe-jook Report - Site 1}

Charles Francis Hall spent the years 1864 to 1869 in a futile search for survivors of the Franklin expedition, and during that period he conducted numerous interviews with Inuit about the expedition (Hall, 1869). One of his key informants was an Inuk named In-nook-poo-zhe-jook, whom Hall interviewed twice (on 2 May and 2 July 1869) on the subject of the ships' boats in Erebus Bay (Hall, 1869: 
Journal B). In-nook-poo-zhe-jook told Hall that several years earlier he, accompanied by several other Inuit, had traveled to the west coast of King William Island to search for materials from the Franklin expedition (Hall, 1869:110). Hall calculated the time of In-nook-poo-zhe-jook's trip to have been the spring of 1861, and his interview notes indicate that In-nook-poo-zhe-jook's group departed from Terror Bay and followed the coastline of Graham Gore Peninsula to reach Erebus Bay (Hall, 1869:109). Hall also noted that In-nook-poo-zhe-jook returned to the boat sites in 1862, but no details of that trip were recorded.

In-nook-poo-zhe-jook told Hall that he and his companions were the first Inuit (and thus, presumably, the first people) to have visited the site since McClintock. Although incomplete in many respects, the information In-nook-poo-zhe-jook provided about the condition of the site is revealing. He stated that snow and ice were found in and all around the boat and that the boat was empty, implying that it was still intact, and perhaps still resting on the sledge. The statement that it was empty suggests that Hobson and McClintock had not placed the items that they had removed back into the boat. Hall (1869:111) listed a small number of relics that were observed or taken from the site by In-nook-poo-zhe-jook's party: specifically, a jackknife, a file, a small axe, a roll of sheet lead, drag ropes, some canvas, and five paddles. Quantities of each of these objects had been left at the site in 1859 , but because In-nook-poo-zhe-jook did not report seeing any of the numerous other items that McClintock reported leaving at the site, Hall expressed doubt about the veracity of In-nookpoo-zhe-jook's claim that his group was the first to have visited the boat since McClintock. However, In-nook-poozhe-jook's description of the snow and ice cover at the site offers a plausible explanation for what Hall considered to be an incomplete inventory. In addition to the artifacts, In-nook-poo-zhe-jook also reported seeing the bones of white men outside of the boat-significantly, several crania partially visible through the melting snow and iceelements that had not been observed at the site by either Hobson or McClintock (Hall, 1869:111).

\section{The 1869 In-nook-poo-zhe-jook Report - Site 2}

In-nook-poo-zhe-jook reported finding two Franklin expedition boats at Erebus Bay in the spring of 1861. From Hall's July 1869 interview, it appears that the first boat the Inuit encountered was the same one previously found by the 1859 McClintock expedition. Hall described the route taken by In-nook-poo-zhe-jook's party from Terror Bay to Erebus Bay as being north along the coast of Graham Gore Peninsula and then "...eastward where they finally found the boat wh. the white men from Ik-ke-lie-suk (Bel-lot Strait) had found before there. Further on about $1 / 2$ a mile ... they found the other boat wh. had not been found by the white men from Bellot Strait" (Hall, 1869:116). Thus, the second boat was apparently found approximately $800 \mathrm{~m}$ east of the one found by McClintock. Confusingly, in
Hall's notes from May 1869, he also placed the location of the second boat as being a "little way westward of the one Hobson found" (Hall, 1869: Book 22).

In-nook-poo-zhe-jook's depiction of the site as recorded by Hall is the only in situ description of the second boat that exists. No information concerning the size or shape of the second boat or the sledge was recorded, but with respect to their condition, In-nook-poo-zhe-jook had evidently dismantled and removed them in 1861 (or possibly during a subsequent visit) (Hall, 1869: Book 22), and Hall apparently came into possession of one of the runners from the sledge on which the second boat had been dragged.

According to In-nook-poo-zhe-jook, the contents of the second boat included paddles, table knives, a watch, telescope, tobacco, dishes, books, and papers: basically, an inventory indistinguishable from that found in the boat discovered by McClintock. He also reported that there was a tent near the boat. Human remains were also present, and on that subject In-nook-poo-zhe-jook provided Hall with vivid details. In describing the contents of the second boat, he told Hall that it contained one complete and clothed skeleton, three skulls, and many other human bones. One of the most shocking details, however, was his description of the quantity and condition of human skeletal remains observed outside of the boat. In-nook-poo-zhe-jook told Hall that there was a "cooking or fire place" alongside of the boat, and that near it there were several skulls, a very large quantity of human bones that had been broken up for their marrow, and some large boots with cooked human flesh in them (Hall, 1869:112).

\section{The 1878-80 Schwatka Expedition}

In 1879, Frederick Schwatka searched the west coast of King William Island between Cape Felix and Erebus Bay in pursuit of records from the Franklin expedition purported to have been buried somewhere in the area (Gilder, 1881; Schwatka, 1965; Klutschak, 1987). His search was the first to be conducted on King William Island during the summer months. On 21 July 1879, he came upon a place in southern Erebus Bay containing human skeletal remains, the wreckage of a boat, and other artifacts deriving from the Franklin expedition. Schwatka presumed that he had found the boat site discovered 20 years earlier by McClintock, but he noted that it was located a considerable distance (10-15 miles east-southeast) from its position as shown on the Admiralty chart (Gilder, 1881:157; Schwatka, 1965:88). Schwatka apparently did not record (or publish) his own coordinates for the location, so its actual position remained unknown for another 114 years.

Schwatka spent several hours at the site collecting artifacts and human remains found scattered over a considerable distance along the shore. All of these items were reported as being found very close to the high-water mark, and their distribution led Schwatka to speculate that the boat might have been abandoned on the sea ice and drifted to shore during breakup. During their time at 
TABLE 1. Estimated minimum number of individuals represented by Franklin expedition human skeletal remains found at Erebus Bay.

\begin{tabular}{lccc}
\hline \hline Site & \# Bones & Estimated MNI & Source \\
\hline NgLj-1 & 24 & $2-5$ & Beattie, 1983 \\
NgLj-2 & 446 & 11 & Keenleyside et al., 1997 \\
NgLj-3 & 77 & 3 & Schwatka, 1965; Stenton et al., 2015 \\
Inook-poo-zhe-jook Site & unknown & 5 & Hall, 1869 \\
\hline \hline
\end{tabular}

the site, Schwatka and his team placed all the items they had found "in a pile" (Gilder, 1881:156) and then selected some to take with them, presumably leaving the remaining items where they had piled them. Many artifacts were left at the site but among the small number that Schwatka removed were the boat's stem, as well as smaller items including rope, sheet lead, combs, and shot. Seventy-six human bones, thought to represent at least four individuals (Klutschak, 1987:94), were collected, counted, and buried nearby, and a stone monument was built over the grave (Schwatka, 1965:89; Stenton et al., 2015). As previously noted, Schwatka (1965:88) stated that his party had searched carefully, but unsuccessfully, for the second boat described to Hall by In-nook-poo-zhe-jook.

\section{Summary of Historical Accounts}

To summarize, the 19th century European search reports and Inuit accounts suggest two boats and sledges from the Franklin expedition were found in southern Erebus Bay. For the first (McClintock) site discovered, there are descriptions of the site from four recorded visits between 1859 and 1879 (i.e., Hobson, McClintock, In-nook-poo-zhe-jook and Schwatka); for the second (In-nook-poo-zhe-jook) site, there is only the description from the one recorded visit. Inuit accounts state that boats and sledges were dismantled at both sites and removed together with quantities of artifacts (e.g., Hall, 1869; Schwatka, 1965).

At the first site, the first two recorded visits occurred in the spring when the site was blanketed by snow and the boat and sledge were intact. Hobson and McClintock's activities resulted in a very detailed site description and artifact inventory; In-nook-poo-zhe-jook's visit provided limited and general observations, certain details of which (e.g., the presence of human crania) differed from the original account of the site. By the time of Schwatka's arrival two decades later, in mid-summer, the site had undergone drastic changes, notably the total destruction of the boat and, apparently, the removal of the sledge (Schwatka, 1965:70). For the second boat site, the only recorded visit took place in the spring, when the site was covered by snow and ice, and very limited information exists.

\section{ARCHAEOLOGICAL INVESTIGATIONS}

Despite the important 19th century discoveries made at Erebus Bay, it was not an area of special archaeological interest prior to the $1980 \mathrm{~s}$. As a result, the archaeological sources for the Erebus Bay boat sites are Beattie (1982, 1983), Ranford (1992, 1994), Bertulli (1995), MacDonald $(1996,1998)$ and our own investigations conducted between 2012 and 2016.

$N g L j-1$

In 1982, Owen Beattie conducted an archaeological survey along the western shore of King William Island, retracing much of the routes of Hobson, McClintock, and Schwatka, from Cape Maria Louisa south to a point several kilometres east of Little Point, which defines the southern boundary of Erebus Bay (Beattie, 1982). In southern Erebus Bay, Beattie found a small number of artifacts and human skeletal remains scattered over a distance of approximately $15 \mathrm{~km}$ of the shorelines of four small and sequential bays located east of Little Point (Fig. 2). From along the shores of Bays 2, 3, and 4, a distance of approximately $3 \mathrm{~km}$, Beattie collected a total of 14 artifacts and 23 human bones, representing a minimum of two individuals and possibly as many as five (Beattie, 1983:74-75) (see Table 1). The artifacts and skeletal remains were widely scattered surface finds, with the exception of 14 partially articulated foot bones embedded in the ground surface. At the head of Bay 3 , a concentration was found of small wood fragments and splinters scattered over a $30 \times 40 \mathrm{~m}$ area. Beattie suggested that this feature was the probable point of origin of the artifacts and human remains, as well as the presumed site of the boat reported by McClintock (Beattie, 1983:75). The site was, and is, officially registered as the McClintock "boat place" and, to our knowledge, this interpretation has never been questioned.

Since 1982, archaeological investigations at $\mathrm{NgLj}-1$ have been very limited. MacDonald and Ranford briefly visited the site in 1994 and reported finding a portion of a human pelvis and several pieces of wood that appeared to be from a boat; however, none of these materials were collected (MacDonald, 1996). We visited $\mathrm{NgLj-1}$ three times between 2013 and 2015 in an effort to further document the site and to relocate the concentration of wood fragments described by Beattie, as well as the possible boat fragments and human remains reported in 1994. A human fibula was found on the surface in 2013, but the search for the wood and boat fragments and the pelvis was unsuccessful.

\section{$N g L j-2$}

In 1992, a decade after Beattie's surveys in Erebus Bay, amateur historian Barry Ranford discovered human skeletal 
remains and Franklin expedition artifacts on the north end of a small tidal islet located approximately $1.2 \mathrm{~km}$ west of $\mathrm{NgLj}-1$. This site, $\mathrm{NgLj}-2$, was investigated the following year by Margaret Bertulli, and it became the first Franklin site on King William Island to be thoroughly documented using contemporary archaeological procedures (Bertulli, 1995). The positions of hundreds of surface artifacts and human remains were mapped in detail, and an $8 \mathrm{~m}^{2}$ area was excavated to facilitate the recovery of several large human bones that were partially embedded in the ground. The investigation yielded more than 300 artifacts and 429 human skeletal remains representing 11 individuals (Bertulli, 1995; Keenleyside et al., 1997). Between 2012 and 2015, an additional 324 artifacts and 17 human skeletal remains were recovered from the site. All of the human remains have been reinterred in a memorial cairn at the site.

\section{$N g L j-3$}

NgLj-3 was discovered by Barry Ranford in 1993 (Ranford, 1994; Bertulli, 1995) and first documented by an archaeologist in 1994 (MacDonald, 1996). When found, the site displayed many of the same general attributes as $\mathrm{NgLj}-2$, with pieces of wood, remnants of naval artifacts, and a small quantity of human skeletal remains scattered over an area of approximately $100 \mathrm{~m}^{2}$. Also present were several large boulders loosely positioned around what appeared to be a partially buried human skull, suggesting the possibility of an interment. MacDonald (1996: Table 1) mapped the locations of 81 artifacts (50 of which were pieces of wood), five human bones, and 25 pieces of animal bone and shell, but nothing was removed from the site. Ranford (1995:4) briefly revisited the site in 1995, and in 1997 MacDonald (1998:3) erected a small stone cairn at the site into which he placed three of the human bones that had been found in 1994. NgLj-3 was not further investigated until 2011, when repairs were made to the burial cairn (Stenton, 2011). Between 2012 and 2015, the site was re-mapped and a total of 412 artifacts were recovered (Table 2). In 2013, the partially buried cranium was excavated; beneath it were found an additional 71 carefully interred human bones that have been confirmed as the ones buried by Schwatka in 1879 (Stenton et al., 2015). All of the human remains have been reinterred in a memorial cairn at the site.

\section{Summary of Archaeological Investigations}

Despite general similarities, archaeologically the three sites are quite different from one another. $\mathrm{NgLj}-1$ is defined by a very small number of widely scattered surface artifacts and human skeletal remains, whereas $\mathrm{NgLj}-2$ is defined by much larger numbers of both artifacts and human remains contained within a much smaller, well-defined area. $\mathrm{NgLj}-3$ is defined by a scatter of materials superficially similar to that at $\mathrm{NgLj}-2$, but also by a deliberate interment of human remains. Having summarized the historical and oral
TABLE 2. Categories of finds from archaeological sites NgLj-1, 2, and 3 in Erebus Bay, King William Island.

\begin{tabular}{|c|c|c|c|}
\hline \multirow[b]{2}{*}{ Artifacts } & \multicolumn{3}{|c|}{ Site } \\
\hline & NgLj-1 & $\mathrm{NgLj}-2$ & $\mathrm{NgLj}-3$ \\
\hline Boat/sled wood fragments & & 140 & 135 \\
\hline Boat/sled fasteners & & 219 & 175 \\
\hline Boat knee braces & & 1 & 1 \\
\hline Barrel parts & 1 & & \\
\hline Other wood & 8 & & \\
\hline Bottle glass fragments & & 2 & \\
\hline Glass lens fragments & & 3 & \\
\hline Other glass fragments & & 16 & 2 \\
\hline Metal can/container fragments & & 60 & 2 \\
\hline Fine metal mesh fragments & & 11 & \\
\hline Fabric & & 36 & 2 \\
\hline Buttons & & 57 & 1 \\
\hline Buckles & & 2 & 3 \\
\hline Shoes & 3 & 11 & \\
\hline Cordage & & 4 & \\
\hline Firearm supplies & & 19 & 41 \\
\hline Fish hooks & & 1 & \\
\hline Combs & & 1 & \\
\hline Handles & 1 & 1 & 1 \\
\hline Knife blades & & 1 & \\
\hline Pipes & 1 & 8 & 4 \\
\hline Thimbles & & 1 & \\
\hline Toothbrush & & 2 & \\
\hline Miscellaneous artifact fragments & & 17 & 1 \\
\hline Metal fragments & & 99 & 42 \\
\hline Leather fragments & & 56 & 2 \\
\hline Total artifacts & 14 & 768 & 412 \\
\hline Human skeletal remains & 24 & 446 & 77 \\
\hline
\end{tabular}

historical accounts and the archaeological investigations, a number of questions about the three sites can now be considered, starting with the identification of the first boat place, the one discovered in 1859 by McClintock.

\section{THE BOAT PLACE SITES}

\section{Identifying the First (McClintock) Boat Place}

Of the three sites under discussion, $\mathrm{NgLj}-2$ can be eliminated from consideration as the boat place discovered by McClintock on the basis that it is inconceivable that when Schwatka rediscovered the McClintock boat place in July 1879, he would somehow have overlooked the hundreds of bones and artifacts found scattered across the site in 1992. Turning to $\mathrm{NgLj-1}$, it was the first site of its type to be discovered in Erebus Bay, and it was identified as the McClintock boat place in the 1980s on the basis of archaeological evidence considered to be consistent with the published account of the discovery - and simply because it was the only archaeological site of its type known from Erebus Bay at the time. Beattie's 1982 survey of the coastline from NgLj-1 east as far as Little Point had discovered no other sites associated with the Franklin expedition.

The 1982 data from $\mathrm{NgLj}-1$ consist of a small number of isolated artifacts and human skeletal remains, most of which were found scattered along the shorelines of 


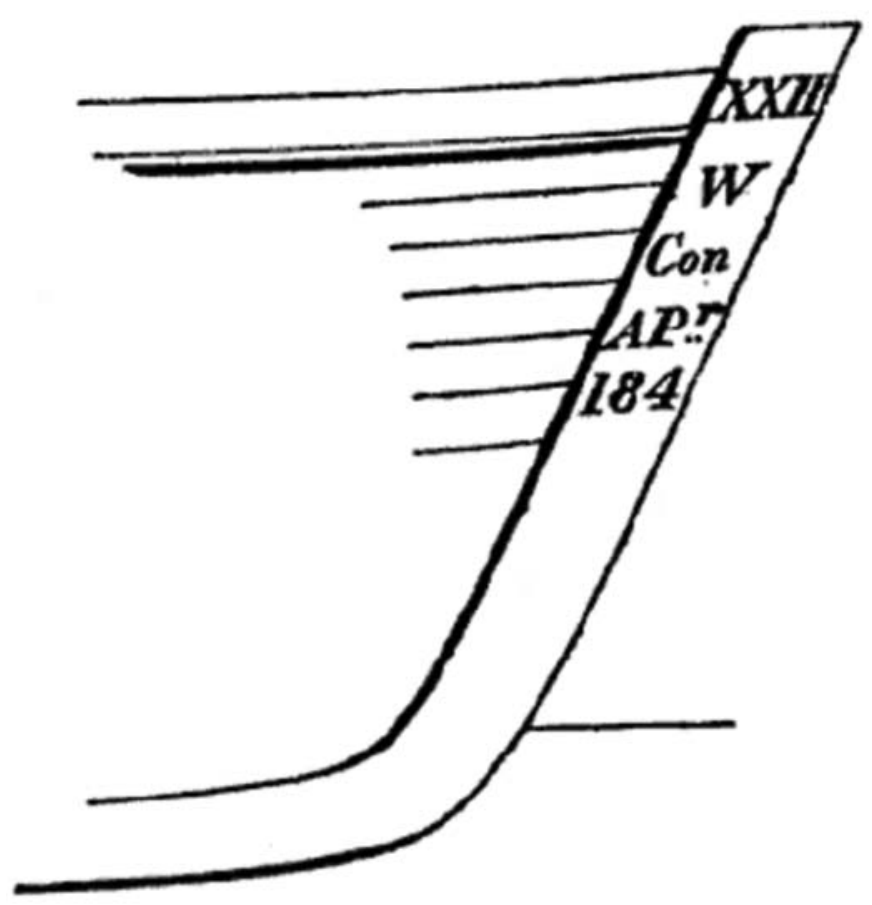

FIG. 3. Sketch of markings on the stem of the boat found in Erebus Bay by the 1857-59 McClintock expedition. (McClintock, 1859:292)

three consecutive and small bays in southern Erebus Bay. The combined length of the shorelines of the three bays surveyed is approximately $3 \mathrm{~km}$, along and near which only 14 artifacts were found. Of these, 12 or $86 \%$ are pieces of wood; the remaining two specimens are pieces of shoe leather. The leather artifacts have diagnostic attributes (e.g., shape, modification for walking on ice) that clearly associate them with the Franklin expedition. The wood artifacts from $\mathrm{NgLj}-1$ have not been the subject of detailed analysis, and thus the association of some of the wood specimens (e.g., boat fragments) recovered from the site with the Franklin expedition is uncertain. However, several objects, including a barrel stave and wood fragments containing square copper tacks and nails, plausibly link these artifacts to the Franklin expedition.

Although the archaeological evidence from $\mathrm{NgLj}-1$ was not inconsistent with McClintock's 1859 description of the boat site, the 1993 discovery of $\mathrm{NgLj}-3$, situated approximately $3 \mathrm{~km}$ west of $\mathrm{NgLj}-1$, threw that identification into doubt. First, the discovery and analysis of the interred human remains (Stenton et al., 2015) confirmed that $\mathrm{NgLj-3}$ was the boat place investigated by Schwatka in 1879, which he identified as the same location discovered by McClintock 20 years earlier. Schwatka based that identification on his discovery of a boat stem that bore markings identical to those on the boat found by McClintock. An illustration of the stem accompanied McClintock's description of it, and the markings are shown in six lines (Fig. 3).

The number of the boat (N 61) appears in McClintock's description of the artifact, but not in the illustration (McClintock, 1859:292). On the actual artifact, it occurs between "Con" and "Apr." McClintock's 1859 illustration of

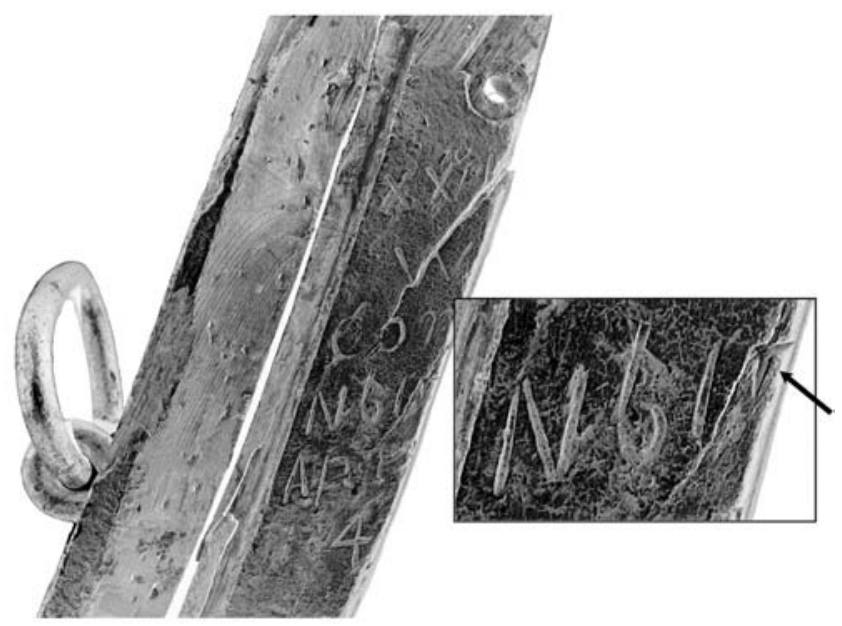

FIG. 4. Detail of markings on the boat stem from $\mathrm{NgLj}-3$. Arrow indicates a partial third digit in the boat's number. Adapted from a photograph provided courtesy of Jonathan Moore, Parks Canada.

the stem markings incorrectly shows the size of the 28 -foot boat, in Roman numerals, as "XXII" or 22 feet. This error was corrected in the 1869 edition, but the number of the boat was not added in the illustration. McClintock (1869:250) noted that the fourth figure to the right of the year stamp was missing, as was part of the Roman numeral indicating the length of the boat, which he attributed to reduction of the stem to lighten the boat for transport via sledge. What appears to have gone unnoticed, however, is that there is a partial third figure to the right of "N 61." Its identification is made difficult by the fact that much of it is missing, but from what remains, it might be the upper part of the number "7" or possibly "5" (Fig. 4).

McClintock (1908:67) carefully reviewed the Schwatka expedition report, and he had no doubt that the remains of the boat found by Schwatka at Erebus Bay were the same boat discovered by Hobson in 1859. However, Schwatka's designation of the stem as the one from the boat found by McClintock was questioned in the 1990s. Woodman (1991:301) stated that the boat stem collected by Schwatka in 1879 from Erebus Bay and later sent to the National Maritime Museum did not bear the markings described by McClintock, suggesting instead that it originated from the other boat discovered by In-nook-poo-zhe-jook. Woodman based this supposition on incorrect information provided to him by the National Maritime Museum. In 1993, when Ranford relocated what he believed to be the site described by Schwatka, he also asserted that it was not the same site discovered by McClintock: "...the stem of the boat that Schwatka carted off does not match that described in McClintock's notes and sketches" (Ranford, 1994:84). The basis for this conclusion is unknown, but it seems probable that the publication of Woodman's book just two years earlier influenced Ranford's thinking on the topic (see Bertulli, 1995:5). In 1995, Coleman (1995:220-222) set the record straight by confirming through an inspection of the actual artifact that the boat stem from Erebus Bay as discovered and described by McClintock and the boat stem 


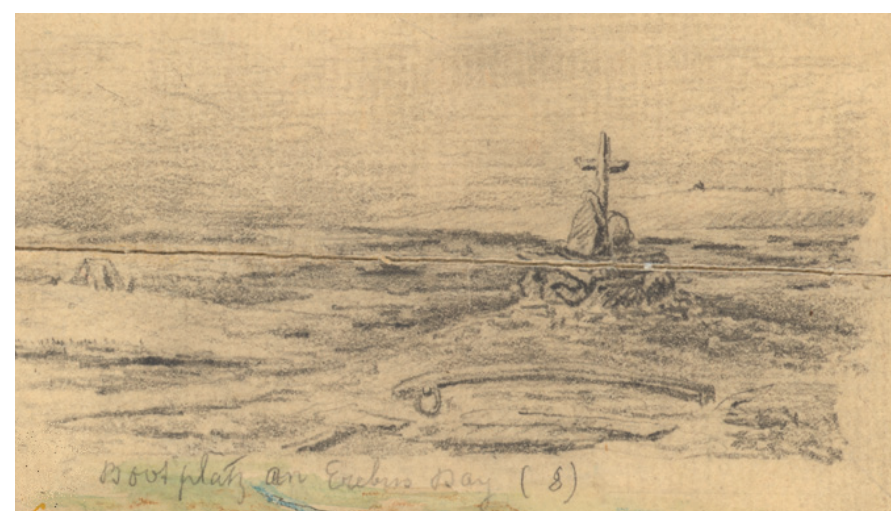

FIG. 5. Drawing by Heinrich Klutschak of burial marker at the McClintock boat place site, Erebus Bay. The boat stem removed from the site by Schwatka is illustrated in the foreground. (Library and Archives Canada, Acc. No. 1993-447-19:f.)

collected by Schwatka and in the possession of the National Maritime Museum were one and the same. Verification of $\mathrm{NgLj}-3$ as the location from which the artifact was recovered is found in a drawing by Heinrich Klutschak, who was a member of the Schwatka expedition. A sketch by Klutschak of the burial cairn erected at the site includes a large piece of wood in the foreground that is unquestionably the boat stem (Fig. 5). Thus, at least part of the same boat found in 1859 by McClintock remained at $\mathrm{NgLj}-3$ in 1879 . Confirmation that $\mathrm{NgLj}-3$ was the same location visited by McClintock, i.e., that the boat stem was still in situ and had not been moved from another location such as $\mathrm{NgLj}-1$, comes from other finds.

The abundant finds at $\mathrm{NgLj}-3$ differ markedly from the small number of artifacts at $\mathrm{NgLj}-1$ and their scattered distribution along several kilometres of shoreline. Wood debris was found at both sites, but at $\mathrm{NgLj}-3$ it was found in significantly larger quantities and in different recovery contexts. Some of the wood artifacts observed or recovered from $\mathrm{NgLj}-1$ are plausibly parts of a boat, but confirmation will require future detailed analyses, including comparisons with wood artifacts recovered from both $\mathrm{NgLj}-2$ and $\mathrm{NgLj}-3$. Potentially linking the artifacts to the Franklin expedition through new analyses is an important step; however, it should be noted that collectively, the $\mathrm{NgLj-1}$ wood artifacts are not indicative or diagnostic of the actual dismantling of a boat, which we know, from historical accounts, occurred at the McClintock site (Fig. 6).

The artifact assemblage from $\mathrm{NgLj}-3$ is instructive on this point. In 1859, McClintock left behind the intact boat and a substantial quantity and variety of items (McClintock, 1859: Appendix III). As previously discussed, Schwatka aggregated what remained of these materials in 1879 and removed a relatively small number of items (Walpole, 2011), some of which were quite large (e.g., the boat stem). Schwatka (1965:88) described the boat as having been "thoroughly overhauled by the natives," and the recovery in recent years from $\mathrm{NgLj}-3$ of large quantities of wood fragments (many perforated by copper and iron fasteners), as well as the number and condition
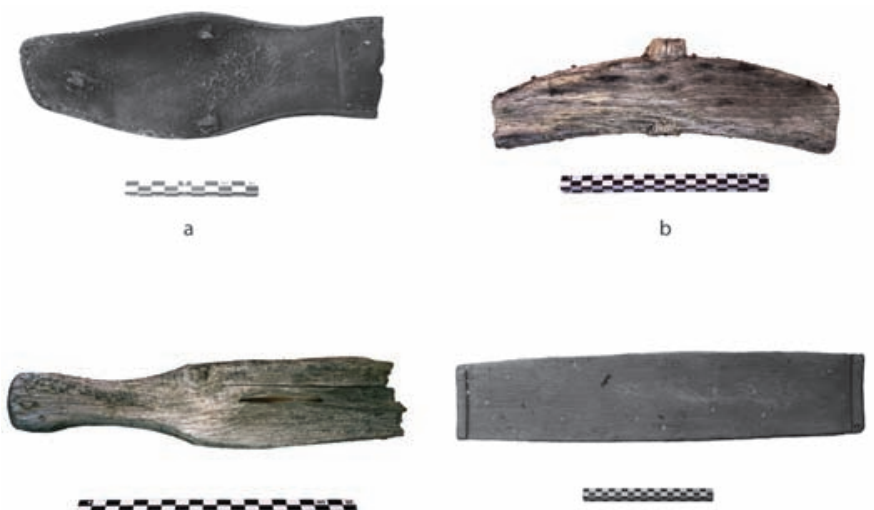

c

d

FIG. 6. Examples of artifacts found at NgLj-1 in 1982: a) leather shoe bottom $(\mathrm{NgLj}-1: 14)$; b) carved wood with large dowel (NgLj-1:12); c) wood handle $(\mathrm{NgLj}-1: 10)$; d) barrel stave (NgLj-1:4). Canadian Museum of History Collection.

of associated fasteners such as copper nails, spikes, tacks, and roves, many of which have been twisted, bent, cut or broken, reflects the dismantling by Inuit of a boat at this location to obtain wood or metal (Fig. 7). These, and other categories of artifacts, such as copper, iron, canvas, glass, rope, buttons, and textiles, are distinctly absent from $\mathrm{NgLj}-1$. As noted, a few of the wood artifacts from $\mathrm{NgLj}-1$ contain square tacks or nails, but there is nothing in the assemblage recovered from the site that would suggest that a large boat or sledge, or even portions thereof, had been dismantled at that location. Furthermore, at $\mathrm{NgLj}-3$ the distribution of artifacts observed in 1993 is consistent with both McClintock's 1859 and Schwatka's 1879 descriptions of the site. Several concentrations of wood have been identified at $\mathrm{NgLj}-3$. One is spatially associated with the grave feature, which we interpret as being derived, at least in part, from the wood cross that was apparently fashioned from pieces of the wrecked boat and used to mark the grave. The others presumably also reflect the 1879 and later collection activities (cf. Schwatka, 1965:88-89). We have collected more than 300 wood specimens from $\mathrm{NgLj}-3$ for future analysis, and a large number of wood fragments still remain at the site. Thus, the direct association between the buried human remains, boat wreckage, and naval artifacts found at $\mathrm{NgLj}-3$ and the recovery there of the boat stem with markings identical to those reported by McClintock confirm beyond any doubt that it is the original "boat place" site discovered by the $1859 \mathrm{McClintock}$ expedition.

\section{Identifying the Second (In-nook-poo-zhe-jook) Boat Place}

Both $\mathrm{NgLj}-1$ and $\mathrm{NgLj}-2$ are located at relatively short distances to the east of $\mathrm{NgLj}-3$ and thus could plausibly fit In-nook-poo-zhe-jook's description of the location of the second boat place. However, for the reasons outlined above, there is no archaeological evidence for the dismantling of a boat at $\mathrm{NgLj}-1$, whereas $\mathrm{NgLj}-2$, like $\mathrm{NgLj}-3$, exhibits compelling evidence that Inuit disassembled a boat there. 

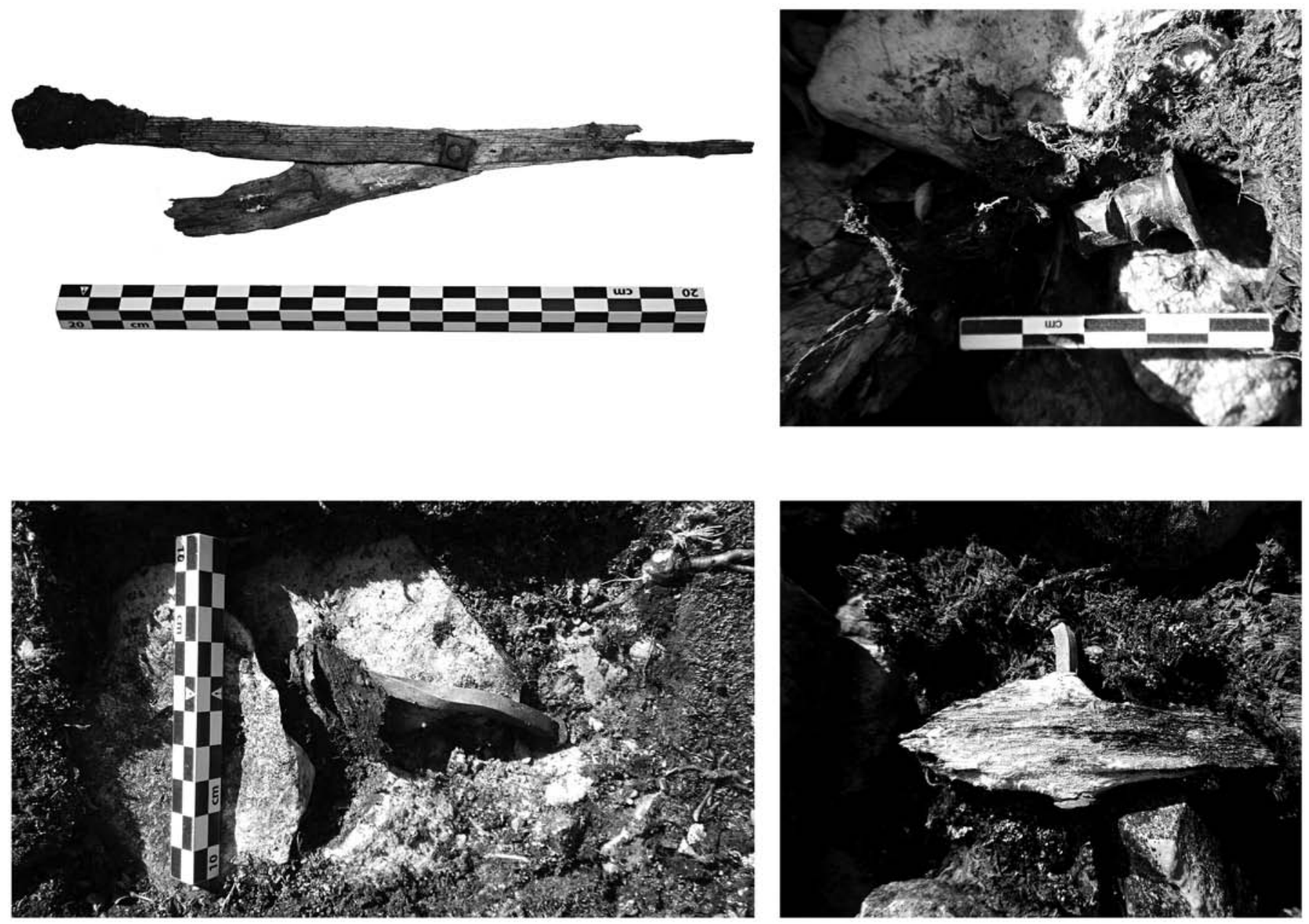

FIG. 7. Examples of artifacts from NgLj-3 reflecting the dismantling of a boat. Clockwise from upper left: two thin wood fragments joined clinker fashion with a copper nail and square rove; broken copper spike with deep chisel mark; wood fragment perforated by broken copper nail; complete and twisted square copper spike perforating wood fragment.

Further, the quantity of human remains and artifacts at $\mathrm{NgLj}-2$ are much more consistent with the original description of the second boat place.

When investigated in $1993, \mathrm{NgLj}-2$ was essentially a debris field with artifacts and human remains scattered over a wide area at the northeast end of the island (Bertulli, 1995:2). From her analysis, Bertulli concluded that $\mathrm{NgLj}-2$ was the probable site of the boat reported by In-nook-poo-zhe-jook (Bertulli, 1995:16). This interpretation was reasonable given the similarities between the brief description of the site as recorded by Hall and the 1993 findings at the site, including the evidence for cannibalism subsequently identified by Keenleyside et al. (1997) in the human remains from the site. To our knowledge, the interpretation of $\mathrm{NgLj}-2$ as the site described by In-nook-poo-zhe-jook has never been questioned. In-nook-poo-zhe-jook's description of the site, however, contains some very specific and important details against which the archaeological data recovered from $\mathrm{NgLj}-2$ in 1993 and 2012-15 can be compared. These comparisons reveal significant inconsistencies that challenge the designation of $\mathrm{NgLj}-2$ as being the site described by In-nookpoo-zhe-jook in 1869.
Hall interviewed In-nook-poo-zhe-jook on at least two occasions about the second boat place, and his original notes from his 2 May 1869 interview include the following passage:

In-nook-poo-zhe-jook tells us that the men who came from the North with 2 sledges; 1 drawn by dogs + the other by men - not a great many years ago [Hobson and McClintock] had found one of these boats + taken away, as he thought, a great many things, while the boat $\mathrm{W}$ [sic] of it had not been touched or found. A great many papers of books + written matter in this boat, not so much of the latter as the former - + these all trash to the Innuits - winds + wet have made destructive work with these - the same trampled under feet of Innuits as through grass. A tent near this boat.

When Hall again interviewed In-nook-poo-zhe-jook on this subject on 2 July 1869, he elicited the following additional details: 


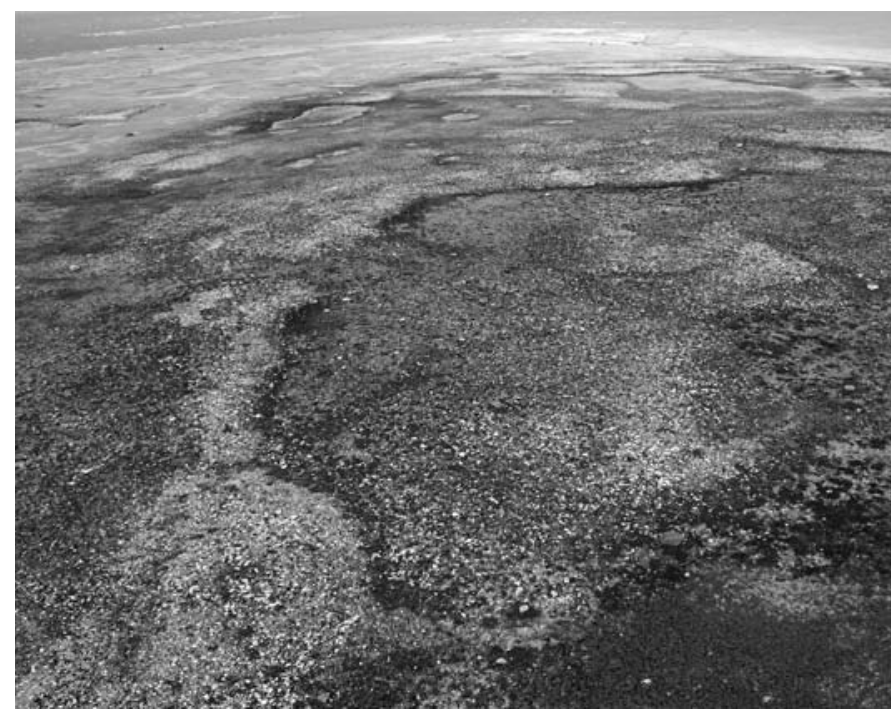

FIG. 8. Aerial view of $\mathrm{NgLj}-2$ showing the absence of built features at the site. The outline of the eight $1 \times 1 \mathrm{~m}$ units excavated in 1993 is clearly visible on the left side of the image.

One whole skeleton with clothes on. This with flesh all on but dried. Many skeleton bones. 3 skulls.

Alongside of the boat a cooking or fire place - some large boots had cooked human flesh in them. Found a jack knife in a boot. A big pile of skeleton bones near the fire place and skulls among them. The number about this boat ama-su-ad-lo (a great many). Cannot tell how many! Is certain that some of the men lived on human flesh - A big pile of human bones that had been broken up for the marrow in them and this pile close to the cooking place.

The first point of comparison between the oral historical and archaeological records is the absence of built features. In-nook-poo-zhe-jook stated that there was a tent near the boat, yet no evidence of a tent has been found at the site. In addition, and conspicuously absent from $\mathrm{NgLj}-2$ in light of other details provided by In-nook-poo-zhe-jook, is the "cooking or fire place" that he reported seeing (Hall, 1869:112). If a hearth or fireplace existed at $\mathrm{NgLj}-2$, some evidence for it would be expected to have survived in the form of stones used to construct a windbreak, the presence and patterned distribution of rocks, charred wood, coal, charcoal, or staining of the ground surface. Such finds are very common from prehistoric Inuit sites dating back millennia, so there is no reason to suspect that they would not have survived at this much more recent site. M. Bertulli (pers. comm. 2014) did not observe any artificial features at the site in 1993, and our own careful examination of the site on multiple visits between 2012 and 2016 also failed to reveal evidence of a tent ring, a constructed fireplace, or any other signs of localized burning (Fig. 8).

The second, and crucial, inconsistency between the site oral history and archaeology is between In-nook-poozhe-jook's description of the human skeletal remains he observed at the site and those remains actually recovered

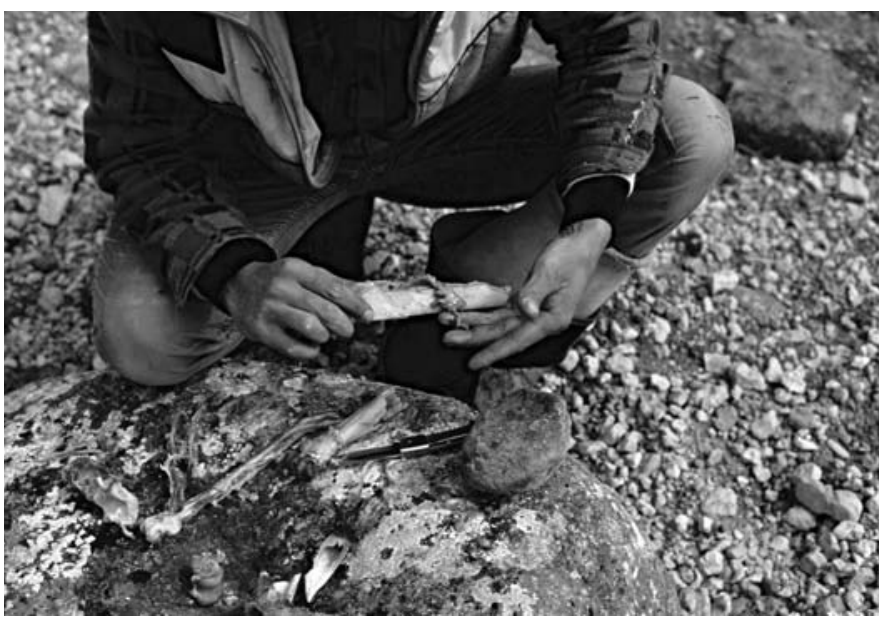

FIG. 9. Tommy Papatsie demonstrating the removal of bone marrow from a caribou metatarsal.

from $\mathrm{NgLj}$-2. In-nook-poo-zhe-jook reported seeing a very large number of human bones at the second boat site, including several crania, and, indeed, five crania and more than 400 other bones have been recovered from $\mathrm{NgLj}-2$ (Bertulli, 1995; Keenleyside et al., 1997). However, key attributes of the human bone assemblage recovered from $\mathrm{NgLj}-2$ contradict, rather than corroborate, In-nook-poozhe-jook's description of the presence of a large pile of human bones that had been broken up for their marrow and were situated near a cooking or fire place. Bone marrow is highly nutritious (Fig. 9), and its consumption can occur as a late stage of starvation cannibalism (e.g., Keys et al., 1950; White, 2014). A recent study suggests the possibility that two human bones recovered from $\mathrm{NgLj}-1$ display attributes characteristic of processing for marrow (Mays and Beattie, 2015). Nevertheless, if human bones had been processed for marrow extraction at $\mathrm{NgLj}-2$ as described by In-nook-poo-zhe-jook, this activity would have resulted in a large and very distinctive bone assemblage that included the presence of articular ends of bones that had been broken from the shafts, bone shaft fragments, and smaller bone fragments displaying breakage patterns characteristic of processing for bone marrow (e.g., Binford, 1978; Lyman, 1994). This is how Inuit usually process caribou bones, and Inuit archaeological sites often contain vast quantities of caribou bones broken in this fashion (e.g., Stenton, 1991) (Fig. 10). In-nook-poo-zhe-jook would have been very familiar with this procedure and with the characteristics of bones processed in this manner, but the $\mathrm{NgLj}-2$ human bone assemblage contains no evidence of marrow processing behaviour. The articular surfaces of several of the recovered long bones appeared to have been chewed off by large mammals, but Keenleyside et al. (1997:40) reported that 57 of the 60 human long bones in the assemblage from $\mathrm{NgLj}-2$ - the bones that contain significant quantities of marrowwere otherwise intact. Only three bones (two radii and one tibia) had been broken, but extensive weathering precluded any determination of when-or, importantly, how - the breakage might have occurred. The NgLj-2 human bones 


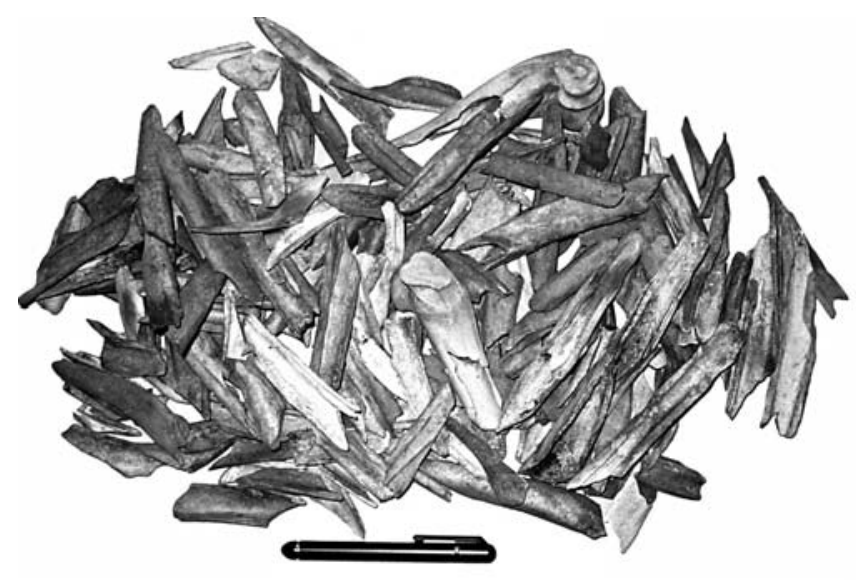

FIG. 10. Caribou long bone fragment assemblage characteristic of bone marrow processing.

do exhibit one form of evidence of cannibalism, in that approximately one-quarter exhibit cut marks suggestive of flesh removal (Keenleyside et al., 1997:40), but this finding does not correspond with In-nook-poo-zhe-jook's very specific description of marrow processing.

Because the sole description of the second boat place is based on 19th century Inuit oral testimony, in assessing $\mathrm{NgLj}-2$ as the possible site reported by Inook-poo-zhejook, we follow the same premise adopted by Woodman (1991:8), namely that "....all Inuit stories concerning white men should have a discoverable factual basis." In the case of $\mathrm{NgLj}-2$, if it is the site described by Inook-poo-zhe-jook, it should contain physical evidence consistent with the details recorded by Hall. Modification of the site through natural and cultural processes undoubtedly occurred during the 132 years between its reported discovery around 1861 and its excavation in 1993. However, the absence of any built features, either intact, disturbed, or repurposed, is significant, and key attributes of the human skeletal assemblage recovered from the site contradict not only the 1869 description of the site, but also the account of specific, late-stage cannibalistic behaviour alleged to have occurred there.

We therefore argue that the archaeological evidence from $\mathrm{NgLj}-2$ does not confirm its identification as the location of the second Franklin boat as reported by In-nook-poo-zhejook in 1869. There are at least three possible explanations for this discrepancy. One is that $\mathrm{NgLj}-2$ is, in fact, the site of the boat found by In-nook-poo-zhe-jook and the absence of the features he mentioned could be the result of shoreline erosion through the impacts of currents, waves, tides, and possibly sea ice movement. However, our observations between 2011 and 2016 suggest that the impacts of water and sea ice did not affect the integrity of $\mathrm{NgLj}-2$ or the neighbouring sites in any significant way. It is interesting to note that at $\mathrm{NgLj}-3$, situated "barely, if at all, above the reach of occasional tides" (McClintock, 1859:292), the boat discovered in 1859 was found intact and still resting on the sledge 11 years after it arrived at that location. At $\mathrm{NgLj}-2$, assuming the boat arrived in 1848, the local environment apparently was not a destructive force during the period of 13 years that preceded its discovery in what is generally accepted as 1861. Comparison of photographs of the site taken between 1993 and 2016 also reveal no obvious indication of disturbance of the site by water or ice during the past 23 years. Thus, no evidence has been found at the site to suggest that the absence of the features in question could be attributable to impacts of the local water or sea ice environments.

A second possible explanation also views $\mathrm{NgLj}-2$ as the site of the boat found by In-nook-poo-zhe-jook, but suggests that for reasons unknown, he dramatically embellished his description of it. We have no means of determining the veracity of In-nook-poo-zhe-jook's account as recorded by Hall and emphasize that we are not concluding that the story, or major elements of it, were indeed fabricated. We note, however, that in Hall's field journals he at times appeared deeply suspicious about the trustworthiness of information provided by In-nook-poo-zhe-jook. Through his interpreter Hannah, Hall prefaced the July 2 interview questions by describing the subjects he wanted to discuss to In-nook-poo-zhe-jook. These subjects included the boats that In-nook-poo-zhe-jook reported finding at Erebus Bay. In the closing sentence, Hall stated: "I also add that I wish him to be very particular to tell me just what he remembers - to tell me the truth and the truth only" (Hall, 1869:105). Subsequently, in his summary of what had been a lengthy interview, Hall characterized In-nook-poo-zhejook as both intelligent and an inveterate liar, the latter a prejudice he apparently also held about the Netsilik in general:

The time occupied in this interview with old In-nookpoo-zhe-jook has occupied fully 6 hours as near as I can judge, and I must here state my opinion of the veracity - I believe he like the other Innuits of Netchille will lie and lie without any regard to consequences. He speaks truth and falsehood all intermingled so that it is impossible to tell which is which only unless it be of matters that one questioning him knows himself the facts. And yet he is a man apparently of honest face. One thing is certain he is a very intelligent Innuit - a great traveler and is a man full of the history of the latter end of Sir John Franklin's Expedition. It is a very great pity that the Netchille Innuits are such consummate liars. Hannah says that 'Jerry' told her several days ago that In-k now and then could not be trusted for he would tell things that were not so.

(Hall, 1869:113-114).

A third possibility is that In-nook-poo-zhee-jook did find a second boat site containing exactly what he described, but that it is not $\mathrm{NgLj-2}$. Given the significant inconsistencies between the oral historical description and the archaeological evidence found at $\mathrm{NgLj}-2$, the existence of an undiscovered third boat site in the area cannot be discounted. It is worth noting that after just a 
few decades, these Franklin expeditions sites would have become increasingly difficult to relocate as a result of being located on a mostly flat and featureless section of Erebus Bay's coastline, of having inaccurate geographic coordinates (if any), and of the progressively diminishing volumes of material evidence resulting from natural and, particularly, cultural forces. For example, Schwatka (1965:88) noted that Inuit told him that the boat and sledge found at the second site had been removed "so completely" that no trace of either could probably be seen, and despite being very familiar with Inuit accounts that there was a second boat place a short distance away, he did not find $\mathrm{NgLj}-2$ or NgLj-1. Beattie's team found NgLj-1, but did not find $\mathrm{NgLj}-2$ or $\mathrm{NgLj}-3$. Vagaries of weather and lighting often mean that one has to be essentially right on top of a site and looking in the right direction to see any remains. Archaeological surveys conducted over the past 30 years in southern Erebus Bay have not revealed any possible candidates for the In-nook-poo-zhe-jook site, but if it has yet to be discovered, its identity would be easily confirmed by the presence of evidence for a tent and for a fire hearth associated with a large, distinctive human bone assemblage produced by marrow extraction processes.

We believe that the fact that other investigators have not remarked on the inconsistency between the historical and archaeological records for $\mathrm{NgLj}-2$ is an instructive example of the enduring influence of historical accounts on interpretations of the Franklin expedition archaeological record. Despite the absence of a clear explanation for the incongruity between the historical and archaeological records, the details in the oral historical account (i.e., the bones broken for marrow, the cooking place, the tent) continue to feature prominently in publications about the Franklin expedition. Accordingly, we think it is important that future depictions of $\mathrm{NgLj}-2$ as being the site described by In-nook-poo-zhe-jook acknowledge the existence of significant discrepancies between the historical description of the site and the archaeological evidence.

\section{NgLj-1 Interpretation}

How, then, is $\mathrm{NgLj}-1$ to be interpreted? We suggest that the wood artifacts attributable to the Franklin expedition and found at $\mathrm{NgLj}-1$ originated nearby, possibly from $\mathrm{NgLj}-2$, and that their distribution primarily reflects transport by wind and water, and not another boat at this precise location. Both site locations are remarkably flat and exposed, with $\mathrm{NgLj}-2$ situated on a tidal islet in Beattie's "Bay 4," and within $20 \mathrm{~m}$ of the high-water mark. NgLj-1 is just over $1000 \mathrm{~m}$ to the east and is separated from $\mathrm{NgLj-2}$ by the waters of Erebus Bay. It is conceivable that lighter materials such as wood and textile fragments could have been transported from $\mathrm{NgLj}-2$ by a combination of strong winds and wave action and deposited elsewhere along the shoreline of Erebus Bay. This explanation would not account for the concentration of small wood fragments observed at $\mathrm{NgLj}-1$ in 1982, but Schwatka's discovery of textile fragments along the shores of inlets in southern Erebus Bay confirms that some expedition materials were being transported by water: "All along the shore at the bottom of the inlets we found pieces of blue navy cloth, which seemed to have been washed up by high tides" (Gilder, 1881:155; cf. Schwatka, 1965:88; Stenton, 2014:521). This explanation suggests a possible source and plausible mechanism for the distribution of some of the artifactual material recovered from the $\mathrm{NgLj}-1$ area.

The number, type, and distribution of the human skeletal remains from $\mathrm{NgLj}-1$ also differentiate it from the 19th century descriptions of the other two boat place sites. At the time they were found, according to historical accounts, each of the boat sites contained hundreds of human bones, including crania and mandibles, within relatively small and well-defined contexts. After more than a century, a reduction in the volume of skeletal material through natural and cultural disturbance processes would not be unexpected. Yet at $\mathrm{NgLj}-1$, only 23 human bones were recovered from multiple collection localities, 14 or $61 \%$ of which were from a partially articulated foot (i.e., from a single individual). The remaining nine bones were widely scattered - three were found in Bay 2, four in Bay 3, one between Bays 2 and 3, and one between Bays 3 and 4. Thus, the small number of bones recovered and (apart from the foot bones) the lack of physical association between them suggest that their distribution might reflect individuals who were members of the groups at $\mathrm{NgLj}-2$ or $\mathrm{NgLj}-3$, and who perished while hunting or during the course of other localized pursuits. The bone distribution might also reflect carnivore activity, including the possible transport of the bones from the other sites. Human skeletal remains from all three of the sites have revealed clear evidence of animal gnawing (Beattie, 1983:73-74; Keenleyside et al., 1997:38; Stenton et al., 2015:35).

\section{SUMMARY AND CONCLUSIONS}

Archaeological investigations at Erebus Bay have confirmed some of what was known from 19th century historical and oral historical accounts about the discovery of ships' boats and of the remains of members of the 1845 Franklin expedition. Archaeological research has also expanded our understanding of events that occurred both during the apparently brief occupation of the sites and over the many decades that followed. However, recent investigations have raised important questions about the influential role of historical accounts in the interpretation of the archaeological record of the Franklin expedition in Erebus Bay (and, by extension, in other locations) and highlighted the need to ensure that all forms of evidence are carefully evaluated.

Historical reports identified two boat places in Erebus Bay, but archaeological research has demonstrated that there are at least three separate sites there that derive directly from the activities of Franklin crew members and 
not from subsequent Inuit or outsider activities: NgLj-1, 2 , and 3. Two of the sites ( $\mathrm{NgLj}-2$ and 3) are places where a ship's boat on a sled ended up and some of its crew members perished. At both sites, there is evidence-in the form of numerous wood fragments and damaged parts and fasteners (e.g., knee braces, nails, bolts, rivets, and roves) - that the boat had been partially or completely dismantled in situ by Inuit. Both sites also contain abundant human skeletal remains that represent substantial portions of complete skeletons. In contrast, $\mathrm{NgLj}-1$ contains a very small number of widely dispersed artifacts, all but two of which are wood, possibly including some wood boat fragments, and a small number of human skeletal remains. The site lacks physical evidence, however, to support its interpretation as a location where the dismantling of a boat in situ occurred, and it seems probable that the finds here were introduced from other nearby sources.

The location of NgLj-2 is roughly consistent with Hall's construal of In-nook-poo-zhe-jook's statement that it was approximately a half mile beyond (i.e., to the east of) the one found by McClintock. However, In-nook-poo-zhe-jook also stated that this second boat place had a tent, a cooking place or hearth, and a large quantity of human bones that had been broken up for marrow extraction. Archaeological research has demonstrated that $\mathrm{NgLj}-2$ has none of those characteristics, some evidence of which should still be visible in the archaeological record if they had existed. Either NgLj-2 is in fact the site of the boat found by In-nookpoo-zhe-jook and he exaggerated his description of what he found there, or In-nook-poo-zhe-jook found a second boat site nearby containing just what he described, somewhere away from $\mathrm{NgLj}-2$ in an as yet undiscovered location. If the site as described by In-nook-poo-zhe-jook is eventually discovered, it will be a potentially very important addition to our understanding of the events that took place at Erebus Bay, particularly with respect to cannibalistic behaviour.

Finally, new investigations and analyses have shown that $\mathrm{NgLj}-3$, and not $\mathrm{NgLj}-1$, is the boat place first discovered by the 1859 McClintock expedition. This conclusion is based on the fact that the stem of the same boat observed by McClintock was found by Schwatka in 1879 at the location where he subsequently interred the human skeletal remains that he found. Archaeological research at $\mathrm{NgLj}-3$ of Schwatka's interment of the skeletal remains (Stenton et al., 2015), as well as the associated debris field resulting from a boat being dismantled at that location, conclusively links this site with the boat found by McClintock.

The sites in Erebus Bay derive from events that presumably occurred soon after the 105 Franklin survivors departed their camp just south of Victory Point, roughly $70 \mathrm{~km}$ to the north, on 26 April 1848 in their attempt to reach the Back River. On the basis of the combined weight of the boat and sledge found in Erebus Bay, McClintock (1859:298) estimated that 20 to 30 men would have been needed to pull each boat on its sledge; if correct, that figure suggests that the survivors set out with no more than five boats. If they experienced conditions similar to those encountered in 1859 by Hobson, who sledged the same coastline at the same time of the year, it seems likely that for safety reasons the boat teams would have attempted to stay fairly close together as they traveled along the coast. The fact that two of the boats were abandoned less than $2 \mathrm{~km}$ apart lends support to this hypothesis.

In his assessment of the discovery of the expedition boat found in Erebus Bay, McClintock speculated that it was returning to the ships-i.e., it had been pulled some distance past Erebus Bay and then reversed course and headed back before being abandoned there (McClintock, 1859:298-299). He based his hypothesis on the direction the boat was pointing (northeastward, toward the position of Erebus and Terror when deserted) and an analysis of the finds he made in it, including the skeletal remains of just two individuals. McClintock did not know that at least one other boat and the remains of at least 11 other men were situated less than $2 \mathrm{~km}$ away, and it is interesting to speculate what his interpretation would have been had he known of it. Schwatka, perhaps influenced by McClintock's thinking, hypothesized that the boat had been abandoned on the ice in Erebus Bay by a party who had dragged it from the camp in Terror Bay (a minimum overland distance of $20 \mathrm{~km}$ across Graham Gore Peninsula, and more than $80 \mathrm{~km}$ if a route following the coast of the peninsula was taken) and it floated ashore when the ice broke up (Schwatka, 1965:88). If that occurred, the orientation of the boat and sledge when found by McClintock would have been accidental. Another possibility is that the orientation of the $\mathrm{NgLj}-3$ boat, which was not attached to the sledge when found in 1859 , was the result of its being moved slightly by water or by ice rafting during the 11 years between its abandonment and its discovery by McClintock, making its orientation coincidental (see Stenton, 2014:518 for Hobson's assessment of the orientation of the boat and sledge).

We suggest also that the existence of the two boats (possibly three, if the site described by In-nook-poo-zhejook has yet to be discovered) so close together is unlikely to be the result of an attempt to return to the ships. If one or more boats had been left behind at Erebus Bay with individuals too weak to proceed and the remaining boats had continued further, a subsequent decision by the advancing party for a group to return to the Erebus and Terror by boat would presumably have involved walking back to Erebus Bay and proceeding from there to the ships in one of the previously abandoned boats, rather than laboriously dragging another boat all the way back. Thus, we conclude that at Erebus Bay the deteriorating strength of the men hauling four or five boats led to a decision to lighten the loads being pulled by simultaneously abandoning at least two of the boats and leaving behind those crew members too weak to proceed further.

In Thomas Smith's famous 1895 painting based on McClintock's boat place, "They forged the last links with their lives," members of the Franklin expedition are depicted as dying in their man-hauling harnesses, having pulled the boat until they dropped. In fact, it is probable 
that the last survivors at each boat performed a number of activities over days or weeks after reaching that location and being left behind by the individuals who proceeded with the remaining boats. At $\mathrm{NgLj}-2$, there is good evidence that some individuals outlived others long enough to resort to cutting (and presumably, consuming) flesh from the bodies of those who had already died, although there is no evidence that they processed their bones for marrow at that location. The crew members possessed firearms and ammunition and some may have ventured away from the boats in attempts to hunt; thus, the human remains along the coast at $\mathrm{NgLj}-1$ may represent men who perished while doing so. At any rate, at these three sites there is no evidence of the kind of proper camp that the Franklin survivors would later establish near the head of Terror Bay, reportedly consisting of a large tent and several graves. It may be that In-nook-poo-zhe-jook's boat place with a tent and evidence of cooking is still to be found at Erebus Bay, but if $\mathrm{NgLj}-2$ is indeed his boat place, then just as at $\mathrm{NgLj}-1$ and 3 , there is no evidence that the crew members survived there for any extended period of time after the others left them behind.

The historic discovery of HMS Erebus in 2014 after more than 160 years of searching was the result of an archaeological research strategy that comprised marine and terrestrial investigations, both of which were developed on a framework of key information contained in historical and oral historical records. The discovery rekindled international interest in the 1845 Franklin expedition and in new interpretations and speculations about the people, places, and events that form integral parts of the expedition story. It also drew attention to the essential role played in the discovery by Inuit oral histories, which, like the other historical source materials, are critically important to understanding past and present theories about the tragic fate of the expedition. We argue that analyses of data obtained through archaeological research have an equally vital role to play, but that these data are often considered only superficially in evaluating current theories, particularly theories that are based substantially on historical narratives. Given the lack of expedition records, archaeological field research and collections analysis are pivotal to gaining a fuller understanding of the events that followed the 1848 desertion of HMS Erebus and HMS Terror, and they offer the only means through which the physical evidence underpinning historical interpretations can be empirically assessed. However, as this study demonstrates, interpretations based on the results of archaeological research must also be critically evaluated.

\section{ACKNOWLEDGEMENTS}

We wish to thank the officers and crew of the Canadian Coast Guard Ship Sir Wilfrid Laurier for providing outstanding logistical support that made new investigations of the Erebus Bay sites possible. Thanks are also extended to Edward Atkinson for his assistance in obtaining copies of Heinrich Klutschak's Franklin search expedition sketches, and to Jonathan Moore for the use of the image of the boat stem. We also thank four anonymous reviewers for their comments and suggestions for improving the paper and extend special thanks to Owen Beattie for his insightful observations and remarks on an earlier version of the paper. This research was funded by the Government of Nunavut Department of Culture and Heritage, Nunavut Archaeology Program.

\section{REFERENCES}

Beattie, O. 1982. The location and analysis of human skeletal remains from the last Sir John Franklin expedition (1845-48) in search of a Northwest Passage. Report of the 1982 Field Survey, N.W.T. Permit \#82-508. Report on file, Department of Culture and Heritage, Heritage Division, PO Box 310, Igloolik, Nunavut X0A 0L0.

- 1983. A report on newly discovered human remains from the last Sir John Franklin expedition. The Muskox 33:68-77.

Bertulli, M. 1995. NgLj-2: A Franklin site on Erebus Bay, King William Island. Field Work in 1993. Report on file, Department of Culture and Heritage, Heritage Division, PO Box 310, Igloolik, Nunavut X0A 0L0.

Binford, L.R. 1978. Nunamiut ethnoarchaeology. New York: Academic Press.

Coleman, E. 1995. Coleman's report of trek on King William Island, 1995. Report on file, Department of Culture and Heritage, Heritage Division, PO Box 310, Igloolik, Nunavut X0A 0L0.

Cyriax, R.J. 1939. Sir John Franklin's last Arctic expedition. London: Methuen \& Co. Ltd.

Gilder, W.H. 1881. Schwatka's search: Sledging in the Arctic in quest of the Franklin records. New York: Charles Scribner's Sons.

Hall, C.F. 1869. Charles Francis Hall Collection, 1858-1871. Washington, D.C.: Archives Center, National Museum of American History, Smithsonian Institution.

Hobson, W.R. 1859. Report of sledge journey, April-June 1859; Lieut. Wm. Hobson, in M'Clintock, Sir Francis Leopold: Arctic Expeditions 1848-1859. Library and Archives Canada, MG 24, H27 (Mfilm A-34).

Keenleyside, A., Bertulli, M., and Fricke, H.C. 1997. The final days of the Franklin expedition: New skeletal evidence. Arctic 50(1):36-46. https://doi.org/10.14430/arctic1089

Keys, A., Brožek, J., Henschel, A., Mickelsen, O., and Taylor, H.L. 1950. The biology of human starvation. Minneapolis: University of Minnesota Press.

Klutschak, H. 1987. Overland to Starvation Cove: With the Inuit in search of Franklin, 1878-1880. Translated and edited by William Barr. Toronto: University of Toronto Press.

Lyman, R.L. 1994. Vertebrate taphonomy. Cambridge: Cambridge University Press. 
MacDonald, J. 1996. 1994 Franklin Search Expedition. Report on file, Department of Culture and Heritage, Heritage Division, PO Box 310, Igloolik, Nunavut X0A 0L0.

- 1998. 1996 Franklin Point Expedition, King William Island, Northwest Territories/Nunavut. Report on file, Department of Culture and Heritage, Heritage Division, PO Box 310, Igloolik, Nunavut X0A 0L0.

Mays, S., and Beattie, O. 2015. Evidence for end-stage cannibalism on Sir John Franklin's last expedition to the Arctic, 1845. International Journal of Osteology 26(5):778-786. https://doi.org /10.1002/oa.2479

McClintock, F.L. 1859. The Voyage of the 'Fox' in the Arctic seas. A narrative of the discovery of the fate of Sir John Franklin and his companions, 1st ed. London: John Murray.

. 1869. The Voyage of the 'Fox' in the Arctic seas. A narrative of the discovery of the fate of Sir John Franklin and his companions, 3rd ed. London: John Murray.

- 1908. The Voyage of the 'Fox' in the Arctic seas. A narrative of the discovery of the fate of Sir John Franklin and his companions, popular ed. London: John Murray.

Nourse, J.E., ed. 1879. Narrative of the Second Arctic Expedition made by Charles Francis Hall: His voyage to Repulse Bay, sledge journeys to the Straits of Fury and Hecla and to King William's Land, and residence among the Eskimos during the years 1864-'69. Washington, D.C.: U.S. Naval Observatory and Government Printing Office.

Ranford, B. 1992. In Franklin's footsteps. Equinox May/June 1992:46-53.
. 1994. Bones of contention. Equinox March/April 1994:69-87.

Schwatka, F. 1965. The long Arctic search: The narrative of Lieutenant Frederick Schwatka, U.S.A., 1878-1880, seeking the records of the lost Franklin expedition. Edited by E.A. Stackpole. Mystic, Connecticut: Maine Historical Association.

Stenton, D.R. 1991. Caribou population dynamics and Thule culture adaptations on southern Baffin Island, N.W.T. Arctic Anthropology 28(2):15-43.

—. 2011. 2011 Franklin Search Expedition - Royal Geographical Society Islands. Report on file, Department of Culture and Heritage, Heritage Division, PO Box 310, Igloolik, Nunavut X0A 0L0.

2014. A most inhospitable coast: The report of Lieutenant William Hobson's 1859 search for the Franklin expedition on King William Island. Arctic 67(4):511-522. https://doi.org/10.14430/arctic4424

Stenton, D.R., Keenleyside, A., and Park, R.W. 2015. The "boat place" burial: New skeletal evidence from the 1845 Franklin expedition. Arctic 68(1):32-44. https://doi.org/10.14430/arctic4454

Walpole, G. 2011. The search for, and an analysis of, the relics of the Franklin expedition 1848-1880. BA thesis, Department of History, Welsh History and Archaeology, Bangor University.

White, T.D. 2014. Prehistoric cannibalism at Mancos 5MTUMR-2346. Princeton: Princeton University Press.

Woodman, D.C. 1991. Unravelling the Franklin mystery: Inuit testimony. Montreal and Kingston: McGill-Queen's University Press. 